\title{
IDENTIFIKASI BAKTERI RESISTEN MERKURI PADA \\ KARANG GIGI, URIN DAN FESES PADA INDIVIDU KELURAHAN PAKADOODAN KOTA BITUNG
}

\author{
Maichel Yorgen, Billy J. Kepel, A.E Manampiring \\ Bagian Kimia, Fakultas Kedokteran, Universitas Sam Ratulangi, Manado \\ email maichelyorgen_faked10@yahoo.co.id
}

\begin{abstract}
ABSTRAK
Merkuri adalah salah satu jenis logam berbahaya yang banyak ditemukan di alam dan tersebar dalam batu - batuan, biji tambang, tanah, air dan udara sebagai senyawa anorganik dan organik. Logam merkuri sangat berbahaya terhadap kehidupan manusia karena dapat memberikan manifestasi klinik yang cukup bermakna mulai dari keracunan, kelumpuhan saraf bahkan dapat meneyebabkan kematian. Salah satu usaha untuk detoksifikasi merkuri dapat dilakukan dengan menggunakan mikroorganisme resisten merkuri seperti bakteri resisten merkuri. Hal itu dapat terjadi jika merkuri yang terpapar dalam tubuh manusia dengan kadar yang kecil dalam waktu yang sangat kronis dapat membuat bakteri dalam tubuh manusia tersebut dapat beradaptasi bahkan dapat mampu meruduksi merkuri tersebut sehingga menjadi tidak berbahaya. Penelitian ini bertujuan untuk mengidentifikasi jenis bakteri yang resisten terhadap merkuri dalam hal ini terhadap jenis merkuri $\mathrm{HgCl}_{2}$ dan fenil merkuri yang terdapat pada karang gigi, urin dan feses pada individu kelurahan Pakadoodan Kota Bitung dengan cara memeriksa kadar resisten bakteri tersebut terhadap merkuri, setelah itu dilakukan uji fisiologi, uji biokimia dan uji morfolgi untuk mengidentifikasi jenis bakteri tersebut. Dari hasil penelitian yang dilakukan terdapat 4 genus bakteri yang berhasil diidentifikasi yaitu Streptococcus sp, E.coli, Bacillus sp, dan Staphylococcus sp. Dengan klasifikasi $\mathrm{HgCl}_{2}$ adalah bakteri dengan genus Bacillus sp yang terdapat pada urin, feses dan karang gigi, dan Staphylococcus sp yang terdapat juga pada urin dengan tingkat resistensi masing-masing 40 ppm dan fenil merkuri adalah bakteri dengan genus Streptococcus sp, yang terdapat pada karang gigi dan E.coli yang terdapat pada feses dan urin dengan tingkat resistensi masing-masing 20 ppm.
\end{abstract}

Kata kunci: merkuri, bakteri, bakteri resisten merkuri

\section{IDENTIFICATION OF THE MERCURY-RESISTANT BACTERIA ON TARTAR, URINE AND FESES UPON THE INDIVIDUAL IN PAKADOODAN VILLAGE OF BITUNG CITY}

\author{
Maichel Yorgen, Billy J. Kepel, A.E. Manampiring
}

Chemistry Departement, Faculty Of Medicine,Universitas Sam Ratulangi, Manado

\begin{abstract}
Mercury is one of kinds of hazardous metals which is highly found in nature and spread in rocklike, ore, soil, water, and air as the inorganic and organic compounds. The metal of mercury is dangerous to human's life because it can cause the substantially clinical
\end{abstract}


manifestations started from being poisoned, nerve palsy and even cause death. One of attempts to mercury detoxification can be done by using mercury-resistant microorganism such as mercury-resistant bacteria. That would happen if the mercury spread inside the human's body with small value in a very chronic time can make the bacteria inside the human's body to be able to adapt even able to reduce mercury so that it becomes harmless. The research aims to identify the kind of bacteria that resists to mercury, in this case, to the kind of mercury $\mathrm{HgCl}_{2}$ and Phenyl Mercury found on tartar, urine, and feses upon the individual in Pakadoodan Village of Bitung City by using the way to check the value of bacteria resistance to mercury, afterwards the Physiology test, Biochemical, and Morphology is done to identify the kind of that bacteria. From the research result done there are 4 genus of bacteria which was successfully identified, those are, Streptococcus sp, E.Coli, Bacillus sp, and Staphylococcus sp. By the classification $\mathrm{HgCl}_{2}$ is the bacteria with the genus of Bacillus $s p$ which is found in urine, feses and tartar, and Staphylococcus $s p$ which is found also in urine with the resistance level of $40 \mathrm{ppm}$ each and phenyl mercury is the bacteria with the genus of Streptococcus sp, which is found in tartar and E.Coli which is found in feses and urine with the resistance level 20 ppm each.

Keywords: mercury, bacteria, mercury-resistant bacteria

\section{PENDAHULUAN}

Merkuri adalah salah satu jenis logam berbahaya yang banyak ditemukan di alam dan tersebar dalam batu - batuan, biji tambang, tanah, air dan udara sebagai senyawa anorganik dan organik. Umumnya kadar merkuri dalam tanah, air dan udara relatif rendah. Berbagai jenis aktivitas manusia dapat meningkatkan kadar ini, misalnya aktivitas penambangan yang dapat menghasilkan merkuri sebanyak 10.000 ton/tahun. Pekerja yang mengalami pemaparan terus menerus terhadap kadar 0,05 merkuri $\mathrm{mg} / \mathrm{m}^{3}$ udara menunjukkan gejala nonspesifik berupa neurastenia, sedangkan pada kadar $0,1-0,2 \mathrm{mg} / \mathrm{m}^{3}$ menyebabkan tremor. Dosis fatal garam merkuri adalah $1 \mathrm{gr} / \mathrm{kg} \mathrm{BB} .^{1}$

Toksisitas neuronal yang disebabkan oleh merkuri organik, misalnya metilmerkuri, merupakan peristiwa keracunan tragis yang terjadi di Jepang dan Irak. Penduduk pantai Minamata di Jepang, yang makanan kesehariannya terutama ikan dari pantai tersebut, terpapar metilmerkuri dalam dosis yang sangat besar akibat limbah industri yang mengandung merkuri berkadar tinggi di buang ke laut. Akibat dari kejadian tersebut ratusan orang mati akibat penyakit yang aneh dengan gejala kelumpuhan saraf. ${ }^{2}$

Akan tetapi, korban yang cedera akibat paparan metilmerkuri justru lebih banyak di Irak. Sekitar tahun 1971 dan 1972 tejadi wabah yang mengakibatkan lebih dari 400 orang meninggal sementara 6000 lainnya dirawat karena intoksikasi berat akibat mengkonsumsi biji-bijian (gandum) yang terlapisi metilmerkuri. ${ }^{3}$

Contoh lain peristiwa keracunan metilmerkuri terjadi di London. Pada abad ke-19, merkuri digunakan dalam industri topi sebagai zat pencegahan pertumbuhan jamur pada topi. Paparan berulang terhadap merkuri menyebabkan pekerja pabrik mengalami tremor dan kerusakan otak sehingga mereka mendapat sebutan "as mad as a hat ter". Pemaparan 
berulang merkuri pada orang dewasa pada awalnya mengakibatkan hilangnya koordinasi, kemudian tremor, masalah pendengaran, kelemahan otot, dan bahkan gangguan mental. ${ }^{4}$

Senyawa organomerkuri terbukti merupakan penyebab dari beberapa epidemi keracunan skala besar yang terjadi di masyarakat baik karena mengkonsumsi ikan yang tercemar atau karena memakan roti yang dibuat dari biji gandum yang sebelumnya disemprot dengan fungisida alkilmerkuri. Metilmerkuri merupakan bentuk merkuri yang paling beracun, terbukti dapat menyebabkan efek yang serius pada sistem saraf, yang pada beberapa kasus berakibat parah dan sangat sulit disembuhkan. ${ }^{5}$

Metil maupun etil merkuri merupakan racun yang dapat mengganggu susunan saraf pusat (serebrum dan serebellum) maupun saraf perifer. Kelainan saraf perifer dapat berupa parastesia, hilangnya rasa pada anggota gerak dan sekitar mulut serta dapat pula terjadi menyempitnya lapangan pandang dan berkurangnya pendengaran. Keracunan merkuri dapat pula berpengaruh terhadap fungsi ginjal yaitu terjadinya proteinuria. Pada karyawan yang terpapar kronis oleh fenil dan alkil merkuri dapat timbul dermatitis. Selain mempunyai efek pada susunan saraf, Hg juga dapat menyebabkan kelainan psikiatri berupa insomnia, nervus, kepala pusing, gampang lupa, tremor dan depresi. ${ }^{6}$

Merkuri yang terdapat dalam limbah atau waste di perairan umum diubah oleh aktifitas mikroorganisme menjadi komponen metilmerkuri (CH3-Hg) yang memiliki sifat racun dan daya ikat yang kuat disamping kelarutannya yang tinggi terutama dalam tubuh hewan air. Hal tersebut mengakibatkan merkuri terakumulasi melalui proses bioakumulasi dan biomagnifikasi dalam jaringan tubuh hewan-hewan air, sehingga kadar merkuri dapat mencapai level yang berbahaya baik bagi kehidupan hewan air maupun kesehatan manusia, yang makan hasil tangkap hewan-hewan air tersebut. ${ }^{7}$

Salah satu usaha untuk detoksifikasi merkuri dapat dilakukan dengan menggunakan mikroorganisme resisten merkuri seperti bakteri resisten merkuri. Detoksifikasi merkuri oleh bakteri resisten merkuri terjadi karena bakteri resisten merkuri memiliki gen resisten merkuri. operon mer. Struktur operon mer berbeda untuk setiap jenis bakteri. Umumnya struktur operon mer terdiri dari gen metaloregulator (merR), gen transfor merkuri (merT, merP, merC), gen merkuri reduktase (merA) dan organo merkuri liase (merB). Bakteri yang hanya memliki gen merkuri reduktase (merA) disebut bakteri resisten merkuri spectrum sempit. Ada beberapa bakteri yang memiliki selain gen merA, juga gen merB maka bakteri tersebut disebut bakteri resisten merkuri spectrum luas. Protein MerA mempunyai fungsi mereduksikan ion merkuri yang toksik menjadi logam merkuri $\mathrm{Hg}(\mathrm{O})$ yang kurang toksik dan mudah menguap pada suhu kamar, sedangkan protein MerB mempunyai fungsi mengkatalisis pemutusan ikatan merkuri-karbon sehingga dihasilkan senyawa organik dan ion $\mathrm{Hg}(\mathrm{II}){ }^{8}$

Sumber pencemaran merkuri dapat disebabkan oleh proses geologi dan biologi. Senyawa merkuri yang terdapat pada air laut kemudian yang akan mempengaruhi biota laut seperti ikan-ikan yang ada di laut, kemudian ikan-ikan yang telah tercemar oleh merkuri secara kronik dalam jumlah yang sedikit tersebut di makan oleh manusia. Hanya saja efek dari merkuri tersebut jarang menimbulkan manifestasi klinik, karena merkuri yang masuk ke tubuh manusia hanya berada dalam jumlah yang sedikit dan terpapar secara kronik. Hal itu mengakibatkan bakteri yang ada dalam tubuh manusia dapat beradaptasi dan telah menjadi resisten atas paparan kronik dari merkuri tersebut, sehingga jarang menimbulkan manifestasi klinik yang bermakna. Apabila bakteri tersebut dapat beradaptasi pada lingkungan dengan tingkat kontaminasi logam berat yang tinggi, maka diasumsikan bahwa penggunaan bakteri 
tersebut sangat efektif dalam meningkatkan reduksi logam berat. Oleh karena itu, mikroorganisme yang terdapat pada daerah tercemar merkuri merupakan sumber untuk isolasi bakteri resisten merkuri. Dalam salah satu penelitian yang telah dilakukan di muara sungai Sario Manado, Sulawesi Utara oleh Fatimawali, $d k k^{9}$ menyimpulakan bahwa salah satu jenis bakteri resisten terhadap merkuri yang dapat mereduksi merkuri organik $\mathrm{Hgcl}_{2}$ menjadi $\mathrm{Hg}^{0}$ adalah bakeri jenis Klebsiella pneumoniae.

\section{METODOLOGI PENELITIAN}

Penelitian ini bersifat eksploratif, dengan metode pengambilan sampel yang digunakan adalah cross sectional. Penelitian ini dilakukan di Kelurahan Pakadoodan Kota Bitung Provinsi Sulawesi Utara, dengan waktu penelitian selama bulan November 2013 Januari 2014. Populasi pada penelitian ini adalah berbagai jenis bakteri yang terdapat pada tubuh manusia, yang mengalami paparan merkuri dalam jumlah yang sedikit dan dalam waktu yang kronis. Sampel yang di ambil pada penelitian ini adalah bekteri yang terdapat pada karang gigi, urin dan feses yang resisten terhadap merkuri pada masyarakat Kelurahan Pakadoodan Kota Bitung. Varibael penelitiannya adalah jenis bakteri yang resisten terhadap merkuri ( $\mathrm{HgCl}_{2}$ dan fenil merkuri). Cara Kerja yang di gunakan adalah uji bakteri yang resisten dengan merkuri, kemudian di lakukan uji fisiologi (Uji Motilitas), uji biokimia (Uji Indol, Uji Katalase, Uji Fermentasi Karbohidrat, Uji sitrat, dan Uji Lysin,), dan identifikasi bakteri menggunakan pewarnaan gram. Data primer diperoleh dari hasil pengamatan langsung di lapangan serta hasil pemeriksaan laboratorium dan kultur bakteri yang dilakukan di laboratorium Mikrobiologi FMIPA UNSRAT Manado. Data Sekunder di ambil dari sumber-sumber yang telah ada, seperti jurnal-jurnal penelitian dan hasil-hasil penelitian terdahulu

\section{HASIL}

\section{HASIL DAN PEMBAHASAN}

Hasil uji bakteri resisten merkuri di dapati bakteri dapat bertahan hidup dengan kadar 40 ppm masing-masing di karang gigi, urin dan feses untuk $\mathrm{HgCl}_{2}$ dan $20 \mathrm{ppm}$ untuk Fenil Merkuri masing-masing di karang gigi, urin dan feses. Selanjutnya dilakukan Uji menggunakan media Natrium Broth untuk memperoleh 1 spesies bakteri murni dari masingmasing isolat. Ditemukan ada 7 spesies bakteri yang di beri kode isolat M.G 20, M.F 20 dan M.U 20 untuk fenil merkuri dan M.G 40, M.F 40, M.U 40 dan M.U 402 untuk $\mathrm{HgCl}_{2}$.

\section{Hasil Uji Morfologi, Uji Fisiologi, dan Uji Biokimia}

\begin{tabular}{|c|c|c|c|c|c|c|c|c|c|c|c|c|c|}
\hline \multirow{3}{*}{$\begin{array}{l}\text { Kode } \\
\text { isolat }\end{array}$} & \multirow{2}{*}{\multicolumn{2}{|c|}{$\begin{array}{c}\text { Uji morfologi } \\
\text { Pewarnaan gram }\end{array}$}} & \multirow{3}{*}{$\begin{array}{l}\begin{array}{l}\text { Uji } \\
\text { fisiologi }\end{array} \\
\text { motil }\end{array}$} & \multicolumn{9}{|c|}{ Uji biokimia } & \multirow[t]{3}{*}{ Hasil identifikasi } \\
\hline & & & & \multirow[t]{2}{*}{ Katalase } & \multirow[t]{2}{*}{ indol } & \multicolumn{4}{|c|}{ Uji fermentasi karbohidrat } & \multirow[t]{2}{*}{$\mathrm{H} 2 \mathrm{~S}$} & \multirow[t]{2}{*}{ Citrat } & \multirow[t]{2}{*}{ Lysin } & \\
\hline & Bentuk & $\begin{array}{l}\text { Bakteri } \\
\text { gram }\end{array}$ & & & & glukosa & Laktosa & sukrosa & gas & & & & \\
\hline M.G 20 & Coccus & Negatif & - & + & + & - & + & + & + & - & + & + & Streptococcus sp. \\
\hline M.F 20 & Coccus & Negatif & + & + & + & - & + & + & + & - & - & - & E.coli \\
\hline M.U 20 & Coccus & Negatif & + & + & + & - & + & + & + & - & + & - & E.coli \\
\hline M.U $40_{1}$ & Bacililli & Negatif & - & + & - & - & + & + & + & - & - & + & Bacillus sp. \\
\hline M.U40 2 & Coccus & Positif & - & + & + & - & + & + & + & + & - & + & Staphylococcus sp \\
\hline M.F 40 & Bacililli & Negatif & + & + & + & - & + & + & - & + & + & + & Bacillus sp. \\
\hline M.G 40 & Bacililli & Negatif & - & + & - & - & + & + & + & - & + & + & Bacillus sp. \\
\hline
\end{tabular}


Breed, Se., E.G.D. Murray and A.P. Hitchens,.1948. Bergey’s Manual Determinative Bacteriology. The William and Wilkins Company, Baltimore. ${ }^{10}$

Hasil Pengamatan Bentuk Koloni, Permukaan, Warna dan Jumlah Koloni

\begin{tabular}{|c|c|c|c|c|c|c|c|}
\hline \multirow{2}{*}{$\begin{array}{l}\text { Kode } \\
\text { isolat }\end{array}$} & \multicolumn{3}{|c|}{ Merkuri $\left(\mathrm{HgCl}_{2}\right)$} & \multicolumn{3}{|c|}{ fenil merkuri } & \multirow[t]{2}{*}{ Ket } \\
\hline & $\begin{array}{l}\text { Bentuk } \\
\text { koloni }\end{array}$ & $\begin{array}{l}\text { Permukaan } \\
\text { koloni }\end{array}$ & $\begin{array}{l}\text { Warna } \\
\text { koloni }\end{array}$ & $\begin{array}{l}\text { Bentuk } \\
\text { koloni }\end{array}$ & $\begin{array}{l}\text { Permukaan } \\
\text { koloni }\end{array}$ & $\begin{array}{l}\text { Warna } \\
\text { koloni }\end{array}$ & \\
\hline M.G 20 & Bulat & Halus & Putih & & & & Streptococcus sp. \\
\hline M.F 20 & Bulat & Halus & Orange & & & & E.coli \\
\hline M.U 20 & Bulat & Halus & Putih & & & & E.coli \\
\hline M.U $40_{1}$ & & & & Bulat & Bergerigi & Putih & Bacillus sp. \\
\hline M.U40 & & & & Bulat & Halus & Putih & Staphylococcus sp \\
\hline M.F 40 & & & & Bulat & Halus & Putih & Bacillus sp. \\
\hline M.G 40 & & & & Bulat & Halus & Putih & Bacillus sp. \\
\hline
\end{tabular}

\section{PEMBAHASAN}

Pada percobaan fisiologi (motilitas) terhadap 7 isolat yang ada ternyata ada 3 isolat yang positif terhadap uji motil, yang dapat dilihat dengan adanya pergerakan dari bakteri yang melebar dari bekas tusukan terhadap media yang digunakan. Hal tersebut juga menunjukan bahwa bakteri tersebut memiliki flagel yang fungsinya untuk pergerakan bakteri. Sedangkan 4 isolat lainya tidak memiliki flagel sehingga tidak ada pelebaran dari pergerakan bekteri pada media tusuk yang dilakukan.

Setelah melakukan uji motil, isolat yang ada langsung di lakukan uji indol yaitu dengan meneteskan reagen kovac. 5 isolat yang menunjukan hasil positif yang ditandai dengan terdapatnya cincin berwarna merah dipermukaan tabung reaksi. Hal itu menunjukan 5 isolat yang ada memiliki enzim triptofanase akan mampu menghidrolisis triptofan menjadi produk-produk metabolik seperti indol, asam piruvat, dan ammonia. Triptofan merupakan asam amino esensial yang dapat teroksidasi oleh enzim triptofanase. ${ }^{11}$

Pada uji katalase seluruh isolat menunjukan hasil yang positif yang di tandai dengan adanya gelembung-gelembung udara. Hal itu menunjukan bakteri yang ada mampu mendegradasi hidrogen peroksida $\left(\mathrm{H}_{2} \mathrm{O}_{2}\right)$, dan memproduksi enzim katalase yang dapat memecahkan hidrogen peroksida menjadi $\mathrm{H}_{2}$ dan $\mathrm{O}_{2}$ yang salah satunya di tandai dengan adanya gelembung-gelembung udara. Peroksida merupakan senyawa yang sangat berbahaya bagi bakteri karena merupakan gas yang bersifat toksik yang menyebabkan rusaknya sel-sel bakteri. $^{11}$

Pada uji $\mathrm{H}_{2} \mathrm{~S}$ yang dilakukan oleh penulis, 2 isolat menunjukan hasil yang positif dengan memperlihatkan endapan berwarna hitam pada tabung reaksi. Hal tersebut berarti bakteri tersebut menghasilkan $\mathrm{H}_{2} \mathrm{~S}$ yang merupakan hasil dari metabolisme protein melalui aktivitas enzimatik bakteri. Sedangkan 5 isolat yang lain memberikan gambaran yang negatif terhadap $\mathrm{H}_{2} \mathrm{~S}$.

Uji fermentasi karbohidrat terdiri dari uji glukosa, laktosa, sukrosa, dan gas. Hasil positif menunjukan kalau bakteri tersebut memproduksi asam yang dapat menurunkan $\mathrm{PH}$ sehingga terjadi perubahan warna pada tabung reaksi, yang berarti bakteri tersebut dapat 
memfermentasi karbohidrat. Sedangkan untuk hasil negatif berarti bakteri tersebut menggunakan nutrisi lain sebagai sumber energi.

Uji sitrat yang dilakukan bertujuan untuk melihat bakteri yang menggunakan sitrat sebagai sumber karbon untuk metabolisme. Hal itu dapat terlihat dari perubahan warna dari hijau menjadi biru yang terdapat pada 4 isolat yang telah dilakukan percobaan. Perubahan warna bakteri ini disebabkan oleh adanya Bronthymol Blue sebagai indikator $\mathrm{pH}$ dan dipengaruhi oleh enzim sitrat permiase. Sitrat permiase ini berperan dalam membawa sitrat dari luar sel ke dalam sel. Sitrat yang telah berada di dalam sel akan masuk ke dalam siklus Krebs. Sitrat merupakan intermediet utama siklus Krebs. Pada siklus Krebs, sitrat akan diubah menjadi asam oksaloasetat dan asam asetat dengan bantuan enzim sitrase. Selanjutnya asam oksaloasetat dan asam asetat dirubah menjadi asam piruvat dan karbon dioksida. Karbon dioksida bereaksi dengan air dan natrium yang terdapat pada media Simmons citrate agar sehingga membentuk natrium bikarbonat. Keberadaan natrium bikarbonat mengakibatkan media bersifat basa sehingga merubah warna indikator bromthymol blue dari hijau menjadi biru. Tes penggunaan sitrat positif ditandai dengan adanya enzim sitrat permiase pada bakteri. ${ }^{11}$

Pada uji lysin yang telah dilakukan 5 isolat bakteri menunjukan hasil yang positif yang di tandai dengan terjadi perubahan warna menjadi warna ungu pada isolat. Hal itu berarti bakteri tersebut mampu melakukan dekarboksilasi asam amino berupa lysin melalui enzim dekarboksilase. Proses dekarboksilasi lysin sering digunakan bakteri untuk menetralisasikan lingkungan asam menjadi basa. Reaksi dekarboksilasi dari suatu asam amino seperti lysin merupakan reaksi pemecahan gugus karboksil oleh enzim dekarboksilase sehingga dihasilkan amin dan karbondioksida. Keberadaan amin menyebabkan perubahan warna pada media isolat menjadi ungu lembayung sedangkan reaksi negatif ditandai dengan warna kuning pada media isolat. ${ }^{11}$

Setelah uji fisiologi dan biokimia telah dilakukan selanjutnya penulis melakukan identifikasi bakteri tersebut. Hal pertama dalam identifikasi adalah mengklasifikasikan golongan bakteri tersebut kedalam gram positif dan gram negatif. Hasilnya terdapat 6 spesies bakteri yang memiliki klasifikasi gram negatif yang ditandai dengan warna merah dan 1 spesies bakteri klasifikasi gram positif yang ditandai dengan warna ungu pada pemeriksaan menggunakan mikroskop. Warna merah yang terlihat dibawah mikroskop dikarenakan Kristal ungu yang melekat pada dinding sel tidak mengendap disebabkan karena adanya lapisan protein lipopolisakarida. Selanjutnya telah diberikan larutan lugol, alcohol 95\% dan Safranin serta aquades maka pada bagian dasar akan tercuci dan larut bersama lapisan tersebut.

Setelah melakukan uji pewarnaan gram, selanjutnya penulis mengidentifikasi jenisjenis bakteri tersebut sesuai dengan hasil uji fisiologi dan biokimia yang ada dengan tabel penuntun menurut Bergey's Manual Determinative Bacteriology ${ }^{10}$, yaitu dengan cara saling mencocokan setiap hasil-hasil percobaan yang ada dengan tabel yang telah ada dipenuntun. Dari hasil tersebut didapati ada 4 genus bakteri yaitu Streptococcus sp, E.coli, Bacillus sp, dan Staphylococcus sp.

Bakteri yang telah ditemukan oleh penulis pada percobaan ini memiliki genus yang tidak jauh berbeda dengan penelitian yang dilakukan oleh Dwi Kartika Masloman yang dilakukan di sungai talawaan di teluk Manado pada tahun 2010. Pada penelitian tersebut dia menemukan dua jenis bakteri yang resisten terhadap merkuri yaitu Bacillus sp dan E.Coli. ${ }^{12}$

Pada kedua penelitian yang telah dibandingkan diatas ternyata memiliki hasil yang tidak jauh berbeda walaupun sampel yang di ambil berasal dari tempat yang berbeda, yaitu di 
sungai talawaan Manado dan pada karang gigi, urin dan feses pada individu Kelurahan Pakadoodan kota Bitung.

\section{KESIMPULAN DAN SARAN}

Dari hasil penelitian yang dilakukan penulis dapat menarik kesimpulan bahwa terdapat 4 genus dari bakteri yang berhasil diidentifikasi berdasarkan penelitian-penelitian yang telah dilakukan yaitu Streptococcus sp, E.coli, Bacillus sp, dan Staphylococcus sp. Dengan klasifikasi $\mathrm{HgCl}_{2}$ adalah bakteri dengan genus Bacillus sp yang terdapat pada urin, feses dan karang gigi, dan Staphylococcus sp yang terdapat juga pada urin dengan tingkat resistensi masing-masing $40 \mathrm{ppm}$ dan fenil merkuri adalah bakteri dengan genus Streptococcus $s p$, yang terdapat pada karang gigi dan E.coli yang terdapat pada feses dan urin dengan tingkat resistensi masing-masing 20 ppm.

Berdasarkan peneletian ini maka penulis menyarankan perlu dilakukan penelitian lebih lanjut mengenai bakteri resisten merkuri terhadap masyarkat kota Bitung sehingga bisa mengetahui lebih banyak lagi bakteri yang dapat melakukan detoksifikasi terhadap merkuri dengan sampel yang lebih banyak. Serta perlu adanya tindakan bioremediasi atau detoksifikasi terhadap pengaruh merkuri yang cukup berbahaya, karena kemungkinan besar telah banyak masyrakat yang terpapar oleh merkuri.

\section{DAFTAR PUSTAKA}

1. Irwan, Syaputra. Efek Toksok Merkuri Metalik Hgo. Available at http://www.forumsains.com/artikel/efek-toksik-merkuri-metalik-hgo/

2. Eto K, Oyanagi S, Itai Y, Tokunaga H,Takizawa Y, Suda I. A fetal type of Minamata Disease: an autopsy case report with special reference to the nervous system. Mol Chem Neuropathol 1992;16:171-86.

3. Bakir F, Damluji SF, Amin-Zaki L, et al.Methylmercury poisoning in Iraq. Science 1973;181:230-41.

4. Hunter D. The diseases of occupations. 4th ed. London: English Universities Press, 1969:314-28.

5. Widyastuti palupi. Bahaya Kesehatan Kimia pada Kesehatan Manusia dan Lingkungan. Jakarta: EGC; 2002. h. 44

6. Sudarmaji, J. Mukono, Corie I.P. Toksikologi Logam Berat B3 dan Dampaknya Terhadap Kesehatan. Jurnal Kesehatan Lingkungan. 2006;2:129-142

7. Putranto, T. R. Pencemaran Logam Berat Merkuri (Hg) pada Air Tanah. Teknik. 2011;32:62-71

8. Barkay, T., S.M. Miller, A.O. Summers. Bacterial Mercury Resistance from Atoms to Ecosystems. FEMS Microbiol. Rev. 27.2003: p.355-384

9. Fatimawali, Badaruddin F, Yusuf I. Isolasi dan Identifikasi Bakteri Resisten Merkuri dari Muara Sungai Sario yang Dapat Gigunakan untuk Detoksifikasi Limbah Merkuri. Jurnal Ilmiah SAINS. 2011;11:282-288 
10. Breed, Se., E.G.D. Murray and A.P. Hitchens,.1948. Bergey's Manual Determinative Bacteriology. The William and Wilkins Company, Baltimore.

11. Anonim. Laporan Lengkap Bekteri. Diunduh dari: http://www.scribd.com/doc/120432206/laporan-lengkap-bakteri.

12. Masloman dwi kartika. Identifikasi Bakteri Resisten Merkuri di Muara Sungai Talawaan di Teluk Manado. Skripsi. Sebagai salah satu syarat untuk memperoleh gelar Sarjana Kedokteran pada Departemen kimia. Fakultas Kedokteran. Universitas Sam Ratulangi. 2010. 